\title{
Perception of Malaysian Credit Cardholders on Conventional Cards in Comparison to Islamic Cards
}

\section{Hussin Nazimah*}

\author{
International Business School (UTM IBS), Universiti Teknologi Malaysia (UTM) International Campus, Kuala \\ Lumpur, Malaysia.
}

*Corresponding author: E-mail: nazimah_hussin@yahoo.com

\begin{abstract}
This study determines the perception of consumers to Islamic Credit Cards (henceforth ICCs) in comparative to Conventional Credit Cards (henceforth CCCs). The aim is to determine whether the low ownership of ICCs was resulted from negative perception of ICCs as compared to CCCs. The data collected via questionnaire survey from Malaysian cardholders revealed that the respondents who accepted the existence of ICCs in the market were five times higher as opposed to those who disagreed. The finding was contradicted to the credit card ownership which revealed that the ownership of CCCs was approximately four times higher than ICCs. Based on the eight variables of perception towards the two products; the study revealed that the respondents perceived ICCs at less comparative advantage compared to CCCs. Hence, the findings support that the low ownership of ICCs resulted from the negative perception on the ICCs compared to CCCs. This paper is useful for banking industry, particularly to the issuing financial institutions in measuring customer perception, which of assistance in the expansion of the market share.
\end{abstract}

Keywords: ICCS, CCCS, Perception, Comparative advantage, Malaysia.

\section{Introduction}

Credit cards, the modern financial innovation through which monetary borrowing is made by consumers from financial institutions. Money is channelled to the borrowers through purchases and cash withdrawals. Credit cards are more attractive than charge and debit cards as they only conditioned the repayment of the monthly minimum payment to enjoy the streams of cashflows through their revolving credit facilities [1]. The minimum payment is only about $1 / 36$ or $1 / 48$ of the full loan amount [2]. Cardholders are also given a grace or interest free period if the full loan amount is paid in time [3]. Credit cards expanded in Malaysia since the 1970s [4]. The market remained monopolised until ICCs entered the market through Al-Taslif by AmBank in 1992 [5]. Hence, ICCs were introduced in the Malaysian market after two decades of CCC monopoly and about a decade after the first Islamic bank, Bank Islam Malaysia Berhad (BIMB), commenced operations in 1983. The introduction of ICCs is a part of the Islamic banking industry development to avoid the interest linked financial instruments of the conventional banking which Muslims are prohibited in dealing. ICCs have become more established in 2002 with the launch of BIMB's ICC or Bank Islam Card [6]. Subsequently, various other financial institutions such as Bank Simpanan Nasional, Maybank, CIMB, and HSBC have come up with their own unique ICCs. However, despite the availability of ICCs that can fulfil the need of Muslims as the Malaysian majority population in escaping riba, the market of ICCs remain small as compared to the conventional counterparts. This is interesting that this paper attempts to seek the empirical evidence of whether such hindrance to patronising the ICCs, especially among the Muslims, is due to negative perception of ICCs or their inferiority over CCCs. To achieve the objective, this introductory section will be followed by Section 2 that provides the literature to examine the gap in the credit card selection factors. Section 3 describes the methodology taken in realising the research aim. Section 4 presents the empirical results and discussions. Lastly, Section 5 concludes the paper by highlighting the main findings of the study and provides recommendations.

\section{Literature Review in Credit Card Selection Factors}

Empirical researches in the determinants of credit card selection have been carried out in various aspects. Slocum and Mathew [7] and Mandell [8] revealed that credit cards are used more for convenience factor among the higher socio-economic classes compared to the lower classes which used for credit feature. While 
Canner and Cyrnak [9] undertaken a more comprehensive study which later showed that the financial position, age and income have positive relationship with those who use credit cards for convenience factor. Furthermore, Barker and Sekerkaya [10] revealed that customers used credit cards primarily for the factor of convenience, followed by safety and access to credit.

Another credit card popular study was produced by Meidan and Davos [11]. The study found that credit card major selection factors are convenience, protection, and economy. The study of Meidan and Davos [11] was replicated by Maysami and Williams [12], Gan and Maysami [13] and Butt et al. [14]. These studies found almost similar results in the selection factors whereby credit cards are selected primarily for convenience, finance and protection. In Malaysia, there are several credit card studies that have been conducted. One of the earlier studies was of Dar-Singh and Othman [15] who revealed the use of credit cards are more of among those married, having children, older age, better educated and higher income. Interestingly, in response to the new entry of ICCs into the Malaysian market, several studies have been carried out. For instance, a study by Mansor and Che-Mat [6] found that CCCs were preferably used by consumers compared to ICCs. This finding was further supported by Choo et al. [16] who revealed the limited ownership of ICCs among Malaysians. Furthermore, Shahwan and Mohd-Dali [17] revealed that there was a low understanding and awareness of ICCs among Malaysian academic staff. A further exploration was made by Shahwan et al. [18] where the relationship of religious index was analysed with the ownership of credit cards. The study found that the level of religious index is not a determinant to the ownership of ICCs. Despite all these credit card selection studies, there is no study which particularly examined the perception of ICCs in comparative to CCCs. Hence, this study is conducted to extend the literature to examine the public perception towards the products, which is important to the issuing financial institutions in improving their products. In Malaysia, it is commonly believed that conventional products are better than Islamic products especially in terms of pricing and scale of services offered. In this light, the main hypothesis established to be explored in this study is 'the respondents perceive CCCs better/superior than ICCs.'

\section{Methodology}

The primary data was collected via the privately funded questionnaire survey in Kuala Lumpur and Selangor from January to March 2010. The sample comprised of Malaysian cardholders which were selected on convenience sampling through self-administered handling. More than 1000 questionnaire were distributed but the usable questionnaires were only 507. The descriptive and inferential statistics of non-parametric tests were used to analyse the data. The questionnaire was initially constructed in dual-languages. Each item was written in English and followed with Bahasa Malaysia. This method was adopted from Universiti Teknologi Malaysia of constructing final examination for undergraduate students of College and Science. Three phases of validation to the questionnaire were conducted involving $\mathrm{PhD}$ students, academia, private sector employees and English lecturers. After the validation, the English set was separated from the Bahasa, producing two questionnaires' sets. The questionnaire comprised of three parts: Part I comprises of the demographic profile such as gender, age, marital status, ethnicity, religion, education, income, employment sector and occupation. These information are useful as they relate in understanding the perception of cardholders; Part II deals with credit card profile such as the number of credit cards held, holding type and ownership period; and, Part III comprises of nine variables: one variable concerns the opinion of cardholders on the existence of ICCs in the market; while other eight variables are comparative statements between CCCs and ICCs, which items are mainly constructed to test the main hypothesis of the study. The eight constructed variables based on the credit card structures and issues are as follows:

\section{Variable 1: CCCS provide a higher credit limit than ICCS \\ Variable 2: CCCS offer better bonus/rewards than ICCS \\ Variable 3: Charges for CCCS are lower than ICCs Variable 4: Requirements for approval of CCCs are easier than for ICCS \\ Variable 5: Having CCCs is more prestigious than ICCS}

Variable 6: CCCs have wider acceptance compared to ICCs

Variable 7: The terms and conditions of CCCS are easier to understand than those for ICCS

Variable 8: ICCS provide religious satisfaction, which is not the case with $C C C S$

The main variables of the study are shown in Fig. 1 as follows:

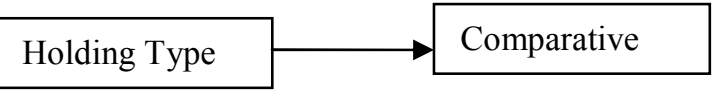

Fig. 1: The Theoretical framework of the study 


\section{Results and Discussion}

\section{Socio-Demographic Respondents}

\section{Characteristics}

The demographic analysis of the 507 respondents is presented in Table 1 , which revealed the following findings:

\section{Gender}

As the findings demonstrate, males comprised $54.5 \%$ of the total sample, which is $10 \%$ higher than females with $45.5 \%$. This result represents the reality of the working force in Malaysia, where men and women are economically active in contributing to the livelihood of the family.

\section{Age}

About $85 \%$ of the respondents are in the age group of 21-40, while the lowest age group is those below 18 with only $0.4 \%$. The latter is expected as 18 years old is the minimum age requirement for getting a credit card. However, it is also important to state that having a majority of the respondents coming from the 21-40 age group is also an indication that this is the working part of the labour force. Further examinations on the age group categories show that the highest percentage is coming from the group of 21-30 years with $48.8 \%$ of respondents. This implies that the credit cards are highly possessed among individuals who can be classified as new and young workers.

\section{Marital status}

As the results in Table 1 show, the percentage of single respondents is only slightly lower than married respondents, $47.8 \%$ and $49 \%$, respectively. The rest of $3.2 \%$ are widowers with $1 \%$ and divorcees. Hence, the single participants are almost equal in proportion with the married participants.

Ethnicity: Ethnically, the sample is highly concentrated with Malays (90.5\%). The rest are Chinese (5.5\%), Indians (3.2\%), and other ethnicities (1.0\%). This result shows that not many non-Malay respondents participated in the study, which is also determined by the demographic nature of the country.

\section{Religion}

The results of religions show a consistency with the ethnic results whereby $90.9 \%$ of the participants are Muslims while others are Buddhists with 4\%, Hindus with 2.6\%, Christians with $2.2 \%$, and others with $0.4 \%$.

\section{Income}

The income group of RM1,500-RM3,000 shows the highest percentage with $48.1 \%$. This is followed by RM3, 000-RM5,000 with 23\%, RM1,001-RM1,500 with $11.4 \%$, RM5,000-RM10,000 with $11 \%$, no income with $2.8 \%$, and above RM20,000 with $0.2 \%$. It is interesting to find that there are nonincome earners among the cardholders. Perhaps, they are supplementary cardholders, or those who are in jobs when applying for credit cards but later experienced job loss. This result indicates that many participants have low income as about $63 \%$ earn less than RM3, 000 a month.

\section{Education}

Among the participants, those with a Diploma/Matriculation/A-Level/Certificate are $36 \%$ of the sample and $35 \%$ have Bachelor degrees. These two academic qualifications are found to be far larger than the other academic qualification groups. Specifically, $1.8 \%$ respondents have Primary school education, 13\% of the participants have secondary school education, $10.5 \%$ have a Master's education, and $1.2 \%$ respondents have a Professional qualification. Hence, the majority of participants have an average level of education with either Diploma/Matriculation/A-Level/Certificate or Bachelor, which combined together, totals to $70.6 \%$ of the whole sample population. This would imply that the respondents are informed knowledgeable.

\section{Employment Sector}

The findings indicate that most of respondents work in the private sector (56.1\%), which is about $20 \%$ higher than those working in the government/public sector $(34.9 \%)$, while $5.4 \%$ of the respondents are in self-employment and $3.6 \%$ are unemployed. Hence, a larger number of respondents are employed in the private sector as opposed to the government sector.

\section{Occupation}

According to the occupational backgrounds of the participants, the largest number of respondents work as Manager/Executive/Businessman with $33.7 \%$, while the second largest occupational group is Clerks (24.4\%), followed by Professionals (15\%), schoolteachers or academicians (10.4\%), technicians $(6.6 \%)$, shopkeepers $(3.4 \%)$, students $(2.8 \%)$, others $(2.6 \%)$, retired $(0.6 \%)$, and factory workers $(0.4 \%)$. Hence, the results fairly support the employment sector, which found that many respondents work in the private sector.

\section{Credit card profile}

Having noted the socio-demographic characteristics of the respondents, it is also important to investigate the respondents' credit card profile. Table 2 depicts the findings of the respondents' credit card profiles. 
Table 1: Distribution of demographic background

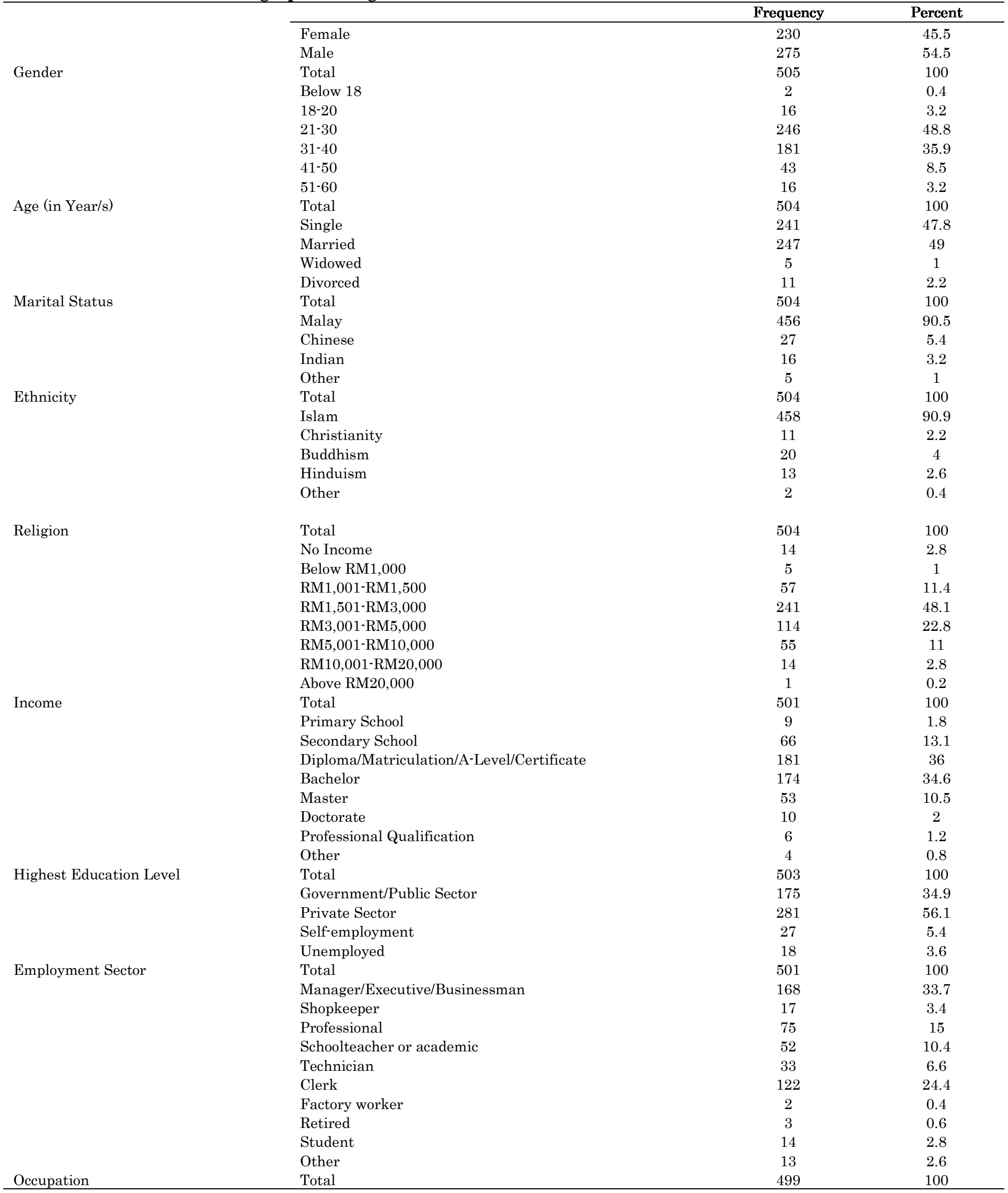

\section{The Number of Credit Cards Held}

The majority of cardholders has 1 card with $47.9 \%$; followed by 2 cards with $30.9 \%$, and 3 cards with $12.7 \%$. A lower percentage is found for those with 4 cards and above. Hence, there is slightly less people with single card ownership (47.9\%) than the multiple owners (52.1\%).

\section{Holding Type}

About two-thirds (69.5\%) of participants possess CCCs, which is far higher than ICC ownerships with only $15.5 \%$. This is interesting as Malaysia has been very eager in promoting Islamic finance, but the credit card taking shows a much greater effort is still required. 


\section{Holding Period}

The highest ownership period is 2 years with $24 \%$, followed closely by 1 year with $21.5 \%$, and 3 years with $13.6 \%$. Generally the percentage of ownership decreased from 3 years onwards with exceptions at 10-year, 12-year, and 14-year. Therefore, it can be concluded that the majority of respondents (59.1\%) has possessed credit cards for 3 years and less. This finding can be partially explained by age factors as the elderly above 40 who participated in the study only comprised $11.7 \%$ of the sample.

\section{The Opinion of the Existence of Islamic Credit Cards}

In seeking the knowledge whether participants believe that there should be ICCs, Table 3 indicates the results to the question. It is found that $66.5 \%$ of participants thought that ICCs should be made available. This is about 5 times higher than those opposing the existence of ICCs with only $13.2 \%$. The rest $20.4 \%$ of participants responded 'no opinion'. Hence, the results show that there is a strong demand for ICCs. It should also be noted that there was a higher percentage of individuals who agreed that ICCs should be in existence, as compared to those who owned ICCs. As can be referred in Table 3, those who demanded ICCs to be offered in the market were $66.5 \%$ as opposed to only $15.5 \%$ of ICC possessors (Table 2).

\section{Perception of Islamic credit cards in comparison to conventional credit cards: the descriptive and inferential analysis}

This section presents the eight statements that explore the perception of ICCs in comparison to CCCs in determining whether respondents perceive CCCs as superior than ICCs through the identified dimensions. The findings of the descriptive statistics for the eight variables are presented in Table 4. As for the statement that 'CCCs have a higher credit limit than ICCs', the results indicate that $38.5 \%$ of cardholders agreed that CCCs provide a higher credit limit while only $16.3 \%$ disagreed. It is also important to note that the majority of participants (45.2\%) are neutral. Regarding the statement that 'CCCs offer better bonus/rewards than ICCs', $34.8 \%$ of the participants agreed and $15.9 \%$ disagreed. The majority, $48.2 \%$, of the participants, however, preferred not to take any position on any side, hence, indicating their scepticism. As to the statement that 'charges for CCCs are lower than ICCs', $21.5 \%$ of respondents agreed that the charges for CCCs are lower when compared to ICCs, while $20.5 \%$ disagreed. More than half of the participants $(57.9 \%)$ remained neutral. With regards to the statement that 'requirements for approval of CCCs are easier than for ICCs', the results in Table 4 show that $34.4 \%$ of the participants agreed that CCCs have easier requirements while $16.6 \%$ disagreed. A large percentage of the participants (49\%) remained neutral.On another dimension concerning whether 'having CCCs is more prestigious than ICCs', the results show that a greater percentage of respondents disagreed (34\%) than agreed $(24.5 \%)$. It is also important to note that the respondents in the neutral group are higher than the other groups.In respect of the statement that 'CCCs have wider acceptance compared to ICCs', about four times of the participants agreed $(50.5 \%)$ than those who disagreed (14.3\%). From the perspective of customers, the result signals that CCCs have better recognition compared to ICCs.In further comparing the various attributes and dimensions of both credit cards, the participants were asked to express their opinion on whether 'The terms and conditions of CCCs are easier to understand than those for ICCs'. The results in Table 4 show that $31.9 \%$ agreed while $17.1 \%$ of the participants disagreed with the statement. The rest of $50.9 \%$ participants remained undecided.In the last statement, the religiosity aspect of credit card holding was examined. The respondents were specifically asked to state their opinion on whether 'ICCs provide religious satisfaction, which is not the case with the CCCs'. The results in Table 4 show that $42.9 \%$ of the participants agreed that ICCs can give them religious satisfaction while only $14.3 \%$ disagreed. However, even in the case of such a statement, $42.7 \%$ of the participants remained neutral. So far, the findings indicated the favourability on CCCs than ICCs; as of findings on the eight statements, six statements relating to 'credit limit', 'charges', requirements for approval', 'wider acceptance' and 'the easiness of credit card terms and conditions' favour CCCs as compared to the rest two statements that favour ICCs in terms of 'prestige' and 'religious satisfaction'. Hence, the overall results strongly suggest that more respondents think that CCCs are better than ICCs in the identified dimensions and attributes. In addition to the descriptive statistics, further exploration on the eight variables to determine whether any association existed between the two holding types, namely CCC holders versus ICC holders, was conducted using chi-square tests. The chi-square analysis was further substantiated with the MannWhitney U. The chi-square test results indicated that four of the eight variables have a significant association. Unfortunately, Mann-Whitney U tests on the four significant variables based on 
Table 2: Credit card profile

\begin{tabular}{|c|c|c|c|}
\hline & & Frequency & Percent \\
\hline & 1 & 242 & 47.9 \\
\hline & 2 & 156 & 30.9 \\
\hline & 3 & 64 & 12.7 \\
\hline & 4 & 25 & 5 \\
\hline & 5 & 11 & 2.2 \\
\hline & 6 & 5 & 1 \\
\hline & 7 & 1 & 0.2 \\
\hline & 13 & 1 & 0.2 \\
\hline \multirow[t]{4}{*}{ The Number of Credit Cards Held } & Total & 505 & 100 \\
\hline & $\mathrm{CCC}$ & 349 & 69.5 \\
\hline & ICC & 78 & 15.5 \\
\hline & MCC & 75 & 14.9 \\
\hline \multirow[t]{20}{*}{ Holding Type } & Total & 502 & 100 \\
\hline & 1 & 98 & 21.5 \\
\hline & 2 & 109 & 24 \\
\hline & 3 & 62 & 13.6 \\
\hline & 4 & 45 & 9.9 \\
\hline & 5 & 45 & 9.9 \\
\hline & 6 & 25 & 5.5 \\
\hline & 7 & 12 & 2.6 \\
\hline & 8 & 8 & 1.8 \\
\hline & 9 & 3 & 0.7 \\
\hline & 10 & 21 & 4.6 \\
\hline & 11 & 3 & 0.7 \\
\hline & 12 & 6 & 1.3 \\
\hline & 13 & 3 & 0.7 \\
\hline & 14 & 5 & 1.1 \\
\hline & 15 & 4 & 0.9 \\
\hline & 18 & 2 & 0.4 \\
\hline & 20 & 2 & 0.4 \\
\hline & 24 & 1 & 0.2 \\
\hline & 25 & 1 & 0.2 \\
\hline Ownership period (in year) & Total & 455 & 100 \\
\hline
\end{tabular}

Table 3: Opinion of ICCs being made available in the market

\begin{tabular}{llll}
\hline & & Should there be ICCs? \\
\hline \multirow{3}{*}{ Valid } & & Frequency & Valid Percent \\
& Yes & 333 & 66.5 \\
& No & 66 & 13.2 \\
& No Opinion & 102 & 20.4 \\
Mean & Total & 501 & 100.0 \\
\hline
\end{tabular}

Table 4: Comparison between ICCs and CCCs

\begin{tabular}{|c|c|c|c|c|c|c|c|c|c|c|c|c|}
\hline & & & & gree & $\mathrm{Ne}$ & tral & & & & $\begin{array}{l}\text { ngly } \\
\text { ree }\end{array}$ & Total & \\
\hline Variable & $\mathrm{N}$ & $\%$ & $\mathrm{~N}$ & $\%$ & $\mathrm{~N}$ & $\%$ & $\mathrm{~N}$ & $\%$ & $\mathrm{~N}$ & $\%$ & $\mathrm{~N}$ & Mean \\
\hline $\begin{array}{l}\text { CCCs provide a higher credit limit } \\
\text { than ICCs } \\
\text { CCCs offer better bonus/rewards than }\end{array}$ & 22 & 4.4 & 59 & 11.9 & 224 & 45.2 & 67 & 33.7 & 24 & 4.8 & 496 & 3.23 \\
\hline $\begin{array}{l}\text { ICCs } \\
\text { Charges for CCCs are lower than }\end{array}$ & 14 & 2.8 & 6 & 13.1 & 2 & 48.2 & 4 & 31 & 24 & 4.8 & 496 & 22 \\
\hline $\begin{array}{l}\text { ICCs } \\
\text { Requirements for approval of } \mathrm{CC}\end{array}$ & 21 & 4.2 & 81 & 16.3 & 287 & 57.9 & 90 & 8.1 & 17 & 3.4 & 496 & 3 \\
\hline $\begin{array}{l}\text { are easier than for ICCs } \\
\text { Having CCCs is more prestigious }\end{array}$ & 12 & 2.4 & 70 & 149 & 242 & 49 & 151 & 30.6 & 19 & 3.8 & 494 & 3.19 \\
\hline $\begin{array}{l}\text { than ICCs } \\
\text { CCCs have wider acceptance }\end{array}$ & 40 & 8.1 & 128 & 25.9 & 206 & 41.6 & 96 & 19.4 & 25 & 5.1 & 495 & 2.87 \\
\hline $\begin{array}{l}\text { compared to ICCs } \\
\text { The terms and conditions of CCCs are } \\
\text { easier to understand than those for }\end{array}$ & 20 & 4 & 51 & 10.3 & 174 & 35.2 & 221 & 44.6 & 29 & 5.9 & 495 & 3.38 \\
\hline $\begin{array}{l}\text { ICCs } \\
\text { ICCs provide religiouls satisfac }\end{array}$ & 14 & 2.8 & 71 & 14.3 & 252 & 50.9 & 146 & 29.5 & 12 & 2.4 & 495 & 3.14 \\
\hline $\begin{array}{l}\text { ICCs provide reli } \\
\text { which is not the ca }\end{array}$ & 1 & 2.6 & 58 & 11.7 & 211 & 42.7 & 159 & 32.2 & 53 & 10.7 & 494 & 3.37 \\
\hline
\end{tabular}


Table 5: Cross-tabulation results between holding type and 'CCCs provide a higher credit limit than ICCs'

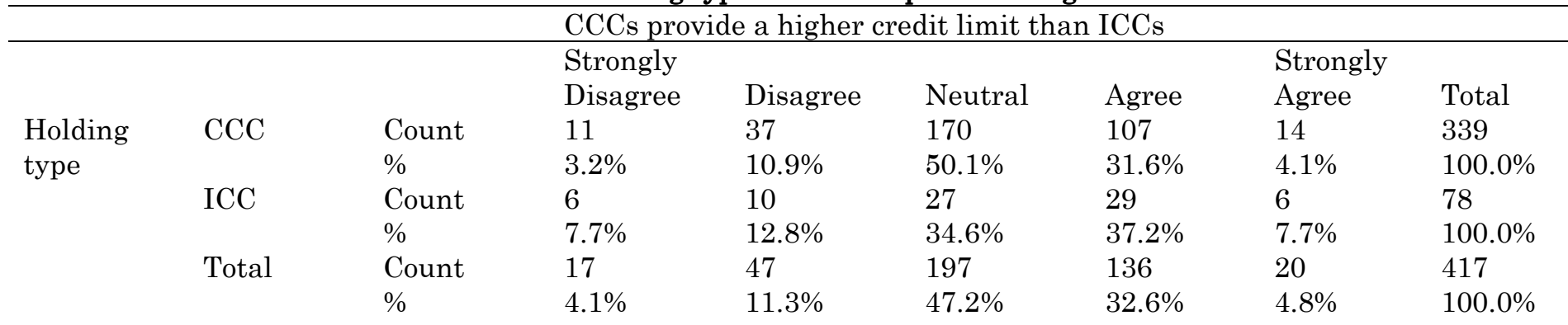

\section{Chi-Square tests}

\begin{tabular}{llll} 
& & Df & Asymp. Sig. (2-sided) \\
\cline { 2 - 4 } Pearson Chi-Square & $8.810^{\mathrm{a}}$ & 4 & .066 \\
Likelihood Ratio & 8.367 & 4 & .079 \\
Linear-by-Linear & .032 & 1 & .858 \\
Association & & &
\end{tabular}

$\mathrm{N}$ of Valid Cases 417

a. 2 cells $(20.0 \%)$ have expected count less than 5. The minimum expected count is 3.18 .

Table 6: Cross-tabulation results between holding type and 'charges for cccs are lower than for ICCS.

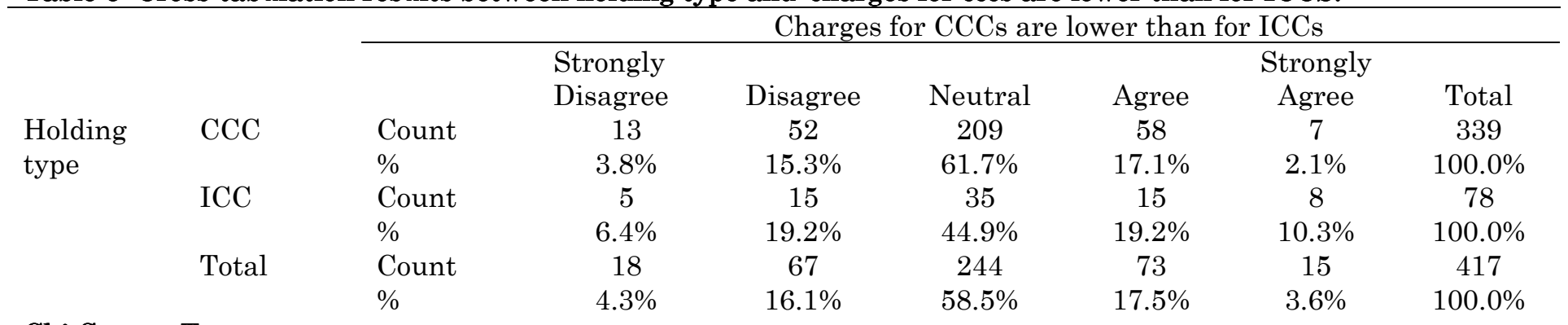

Chi-Square Tests

\begin{tabular}{lllll} 
& Value & df & $\begin{array}{l}\text { Asymp. } \\
\text { sided })\end{array}$ & Sig. \\
\cline { 2 - 4 } Pearson Chi-Square & $16.615^{\mathrm{a}}$ & 4 & .002 \\
Likelihood Ratio & 13.861 & 4 & .008 \\
Linear-by-Linear & .868 & 1 & .351
\end{tabular}

Association

417
expected count less than 5 . The minimum expected count is 2.81 .

$\mathrm{N}$ of Valid Cases

a. 2 cells $(20.0 \%)$ have expected count less than 5 . The minimum expected count is 2.81 .

Table 7: Cross-tabulation results between holding type and 'requirements for approval of CCCs are easier than for ICCs'

\begin{tabular}{|c|c|c|c|c|c|c|c|c|}
\hline & & & Requireme & for appro & f CCCs a & sier the & ICCs & \\
\hline & & & Strongly & & & & Strongly & \\
\hline & & & Disagree & Disagree & Neutral & Agree & Agree & Total \\
\hline Holding & $\mathrm{CCC}$ & Count & 6 & 42 & 180 & 99 & 12 & 339 \\
\hline type & & $\%$ & $1.8 \%$ & $12.4 \%$ & $53.1 \%$ & $29.2 \%$ & $3.5 \%$ & $100.0 \%$ \\
\hline & ICC & Count & 5 & 10 & 30 & 27 & 5 & 77 \\
\hline & & $\%$ & $6.5 \%$ & $13.0 \%$ & $39.0 \%$ & $35.1 \%$ & $6.5 \%$ & $100.0 \%$ \\
\hline & Total & Count & 11 & 52 & 210 & 126 & 17 & 416 \\
\hline & & $\%$ & $2.6 \%$ & $12.5 \%$ & $50.5 \%$ & $30.3 \%$ & $4.1 \%$ & $100.0 \%$ \\
\hline
\end{tabular}

\section{Chi-Square Tests}

\begin{tabular}{llll} 
Chi-Square Tests & \multicolumn{3}{c}{} \\
\hline & Value & df & Asymp. Sig. (2-sided) \\
\hline Pearson Chi-Square & $9.848^{\mathrm{a}}$ & 4 & .043 \\
Likelihood Ratio & 8.704 & 4 & .069 \\
Linear-by-Linear & .028 & 1 & .866 \\
Association & 416 & & \\
N of Valid Cases & 4 &
\end{tabular}

a. 2 cells $(20.0 \%)$ have expected count less than 5 . The minimum expected count is 2.04 . 
Table 8: Cross-tabulation results between holding type and 'having CCCs are more prestigious than ICCs'

\begin{tabular}{|c|c|c|c|c|c|c|c|c|}
\hline \multirow{8}{*}{$\begin{array}{l}\text { Holding } \\
\text { type }\end{array}$} & \multirow{4}{*}{$\mathrm{CCC}$} & & \multicolumn{6}{|c|}{ Having CCCs are more prestigious than ICCs } \\
\hline & & & $\begin{array}{l}\text { Strongly } \\
\text { Disagree }\end{array}$ & Disagree & Neutral & Agree & Strongly & Total \\
\hline & & Count & 16 & 96 & 146 & 65 & 15 & 338 \\
\hline & & $\%$ & $4.7 \%$ & $28.4 \%$ & $43.2 \%$ & $19.2 \%$ & $4.4 \%$ & $100.0 \%$ \\
\hline & ICC & Count & 15 & 11 & 26 & 19 & 7 & 78 \\
\hline & & $\%$ & $19.2 \%$ & $14.1 \%$ & $33.3 \%$ & $24.4 \%$ & $9.0 \%$ & $100.0 \%$ \\
\hline & Total & Count & 31 & 107 & 172 & 84 & 22 & 416 \\
\hline & & $\%$ & $7.5 \%$ & $25.7 \%$ & $41.3 \%$ & $20.2 \%$ & $5.3 \%$ & $100.0 \%$ \\
\hline
\end{tabular}

Chi-Square Tests

\begin{tabular}{|c|c|c|c|}
\hline & Value & $\mathrm{df}$ & $\begin{array}{l}\text { Asymp. Sig. } \quad\left(2^{-}\right. \\
\text {sided })\end{array}$ \\
\hline Pearson Chi-Square & $27.694^{\mathrm{a}}$ & 4 & .000 \\
\hline Likelihood Ratio & 24.241 & 4 & .000 \\
\hline $\begin{array}{l}\text { Linear-by-Linear } \\
\text { Association }\end{array}$ & .002 & 1 & .968 \\
\hline $\mathrm{N}$ of Valid Cases & 416 & & \\
\hline
\end{tabular}

Table 9: Mann-Whitney $U$ test results between holding type and perception variables of ICCs in comparison to CCCs

\begin{tabular}{|c|c|c|c|c|c|}
\hline Variable & & $\mathbf{N}$ & $\begin{array}{l}\text { Mean } \\
\text { rank }\end{array}$ & $\mathbf{Z}$ & $\begin{array}{c}\text { Asymp. sig. } \\
\text { (2-tailed) }\end{array}$ \\
\hline \multirow[t]{3}{*}{ 1. CCCs provide a higher credit limit than ICCs* } & $\mathrm{CCC}$ & 339 & 207.34 & & \\
\hline & ICC & 78 & 216.22 & & \\
\hline & Total & 417 & & -0.634 & 0.526 \\
\hline \multirow[t]{3}{*}{ 2. Charges for CCCs are lower than ICCs*** } & $\mathrm{CCC}$ & 339 & 207.35 & & \\
\hline & ICC & 78 & 216.15 & & \\
\hline & Total & 417 & & -0.654 & 0.513 \\
\hline 3. Requirements for approval of CCCs are easier than for & $\mathrm{CCC}$ & 339 & 206.93 & & \\
\hline \multirow{2}{*}{ ICCs** } & ICC & 77 & 215.4 & & \\
\hline & Total & 416 & & -0.608 & 0.543 \\
\hline \multirow[t]{3}{*}{ 4. Having CCCs are more prestigious than ICCs\# } & $\mathrm{CCC}$ & 338 & 207.66 & & \\
\hline & ICC & 78 & 212.15 & & \\
\hline & Total & 416 & & -0.313 & 0.754 \\
\hline
\end{tabular}

Notes: $\#, * * *, * *, *$ stands for results that are based on chi-square cross-tabulation denoting significance at $0 \%, 1 \%, 5 \%, 10 \%$ level, respectively. $\mathrm{N}$ denotes the number of observations. The four variables that have no significant association are 'CCCs offer better bonus/rewards than ICCs', 'CCCs have wider acceptance compared to ICCs', 'the terms and conditions of CCCs are easier to understand than those for ICCs' and 'ICCs provide religious satisfaction, which is not the case with CCCs'.

chi-square revealed no significant differences. However, the results are still being reported in Table 9 as the Mann-Whitney U results are only used to check the direction of the agreements in complementing the chi-square with the crosstabulation results. The discussions of the variables that have significant associations on chi-square tests together with the complementary test of the Mann-Whitney $U$ are presented as follows: The chi-square finding in Table 5 shows a statistically significant association between holding type and the statement that 'CCCs provide a higher credit limit than ICCs' at the $10 \%$ level with $\mathrm{p}$-value .066 . It is found that the accepting groups from both CCCs and ICCs are greater than their rejecting group (35.5\% than $14.1 \%$ and $44.9 \%$ than $20.5 \%$, respectively). An inspection on the Mann-Whitney U Test results in Table 9 show a statistically insignificant difference between the holding of CCCs and ICCs across the agreement levels of the statement. However, the results show that the mean ranking value of ICCs is 216.22 , which is higher than that of CCCs with 207.34. Although insignificant, the findings imply that ICC holders believe that CCCs offer a higher credit limit to customers than ICCs. This can be positively interpreted to ICCs as lower credit limit may mean a lower debt impact. From another perspective, it also signals a more limited access to credit offered by ICCs than CCCs.

The chi-square finding in Table 6 shows significant associations between holding type and the statement that 'charges for CCCs are lower than ICCs' at the 1\% level with $\mathrm{p}$-value .002 . Regarding CCCs, its accepting group is almost no different to the rejecting group (19.2\% and $19.1 \%$, respectively), while for ICCs, the accepting group $(29.5 \%)$ is much larger than its rejecting group (25.6\%). The Mann-Whitney U Test results in Table 9 reveal the mean ranking value for ICCs (216.15) is higher than that of CCCs (207.35). 
Hence, there is a higher acceptance level among ICC holders than CCC holders towards the statement of 'CCCs having lower charges than ICCs'. This may offer a positive perspective to ICCs as the ICC holders may hold ICCs for religious factors.

The chi-square finding in Table 7 shows a significant association between holding type and 'requirements for approval of CCCs are easier than for ICCs' at the 5\% level with p-value .043. For both CCCs and ICCs, the accepting groups were greater than the rejecting groups $(32.7 \%$ than $14.2 \%$ and $41.6 \%$ than $19.5 \%$, respectively). In addition, the Mann-Whitney U Test in Table 9 indicates a higher mean ranking value for ICCs (215.40) than CCCs (206.93). This means that ICC holders have a greater tendency to believe that CCCs have much easier requirements to be approved for a credit card than ICCs than those of CCC holders.

The chi-square finding in Table 8 shows a full statistically significant association between the holding type and the statement that 'having CCCs are more prestigious than ICCs' at p-value .000 . For CCC holders, there are more respondents who disagreed with the statement than those who agreed (33.1\% than 23.6\%). However, for ICC holders, there are equal distribution among the disagreeing, neutral, and agreeing groups with $33.3 \%$ for each. Further observation of the MannWhitney U Test results in Table 9 found the mean ranking value of ICCs with 212.15 to be higher than CCCs with 207.66. Hence, the mean ranking value findings summarise that ICC holders have a greater tendency to believe that 'CCCs are more prestigious than ICCs'.

Overall, as the four significant variables showed that ICC holders perceive CCCs as superior than ICCs as compared to CCC holders, it is concluded that CCCs are superior to ICCs. Hence, the established hypothesis in this study is accepted.

\section{Conclusion}

The aim of the paper is to determine the perception of Malaysian cardholders towards ICCs in comparative to CCCs. The descriptive

\section{References}

1. Chakravorti S, Emmons WR (2003) Who pays for credit cards? The J. Consumer Affairs. 37(2):20829.

2. Chien YW, Devaney SA (2001) The effects of credit attitude and socioeconomic factors on credit debt and installment debt. The J. Consumer Affairs 35(1):162-79.

3. Brito DL, Hartley, PR (1995) Consumer rationality and credit cards. Journal of Political Economy, 103(2):400-33. statistics revealed that CCCs are superior in terms of six aspects, namely higher credit limit, better bonus/rewards, low charges, easier requirement for approval, wider acceptance and the easiness in understanding the stipulated credit card terms and conditions, as compared to only two aspects of prestige and religious satisfaction that favour ICCs. Further tests of chisquare show that four statements show significant difference with the holding type, namely 'CCCs provide a higher credit limit than ICCs', 'Charges for CCCs are lower than ICCs', 'Requirements for approval of CCCs are easier than for ICCs' and 'Having CCCs are more prestigious than ICCs', which revealed that ICC holders had a higher agreement level over the superiority of CCCs than the CCC holders. Further tests of the Mann-Whitney $U$ have complemented the findings of the agreement directions of the chi-square tests.In general, the results suggest that the respondents perceive CCCs are superior to ICCs. However, the fact that ICC holder agreed more than the CCC holders over the superiority of CCCs, offers a marginal advantage to Islamic banking as the loyalists may be of those religious adherence, which explained why the respondents still hold ICCs despite their expressions on ICC inferiority. From another perspective, as the market of ICCs is still small compared to CCCs, this should trigger the Islamic banking to further improve the perception of the customers on the Islamic banking products. Perhaps there is still high suspicion exists over the level of religiosity of Islamic financial products, especially among Muslims who possess CCCs instead of ICCs. Therefore, aligning ICC structures to the Islamic moral aspiration to reduce the negative perception is necessary.

\section{Acknowledgement}

The author would like to express special thanks to Dr Mehmet Asutay and Professor Rodney Wilson from Durham University and Dr Muslim Amin from Universiti Teknologi Malaysia, International Business School on their fruitful comments.

4. Loke YJ (2007) Determinants of merchant participation in credit card payment schemes. Review of Network Economics 6(4):474-494.

5. Billah MB (2007) Islamic credit card in practice. J. Islamic Banking \& Finance 25:35-42.

6. Mansor N, Che-Mat (2009) Islamic credit card: are demographic factors a good indicator? Asian Social Science 5(12):17-26. 


\section{Available online at www.managementjournal.info}

7. Mathews HL, Slocum JW (1969) Social class and commercial bank credit card usage. J. Marketing, $33: 71-8$.

8. Mandell L (1972) Credit Card Use in the United States. Ann Arbor, MI: Braun \& Brumfield.

9. Canner GB, Cyrnak AW (1986) Determinants of consumer credit card usage patterns. J. Retail Banking, 8(1):9-18.

10. Barker T, Sekerkaya A (1992) Globalisation of credit card usage: The Case of a Developing Economy. Int. J. Bank Marketing 10(6):27-31.

11. Meidan A, Davos, D (1994) Credit and Charge Cards Selection Criteria in Greece. International Journal of Bank Marketing, 12(2):36-44.

12. Maysami RC, Williams JJ (2002) Credit and Charge Card Selection Criteria in Singapore. Paper presented at the Pacific Basin Finance, Economics and Accounting 10th Annual Conference, Singapore 7-8 August.

13. Gan LL, Maysami RC (2006) Credit Card Selection Criteria: Singapore Perspective (2006/10). Economic Growth Centre working paper, School of Humanities and Social Sciences, Nanyang Technological University, Singapore.
14. Butt BZ, Rehman KU, Saif MI and Safwan N (2010) Customers' Credit Card Selection Criteria in Perspective of an Emerging Market. African J. Business Management 4(13):2934-40.

15. Dar-Singh IK, Othman MN (1995) Psychographic and demographic profiles of credit card and noncredit cardholders in urban Malaysia. Journal Pengurusan 14(1):59-79.

16. Choo SY, Lim HE, Sanusi NA (2005) The Consumer Choice of Islamic-based Credit Card: An Analysis of Bivariate Probit Model. In Prosiding Seminar Ekonomi dan Kewangan Islam 2005. Universiti Utara Malaysia.

17. Shahwan S, Mohd-Dali NRS (n.d.) Islamic Credit Card Industry in Malaysia: Customers' Perceptions and Awareness. Malaysia.

18. Shahwan SH, Salleh S, Shafii Z (2008) The Attitude Towards Shariah-Based Credit Card in Islamic Framework: An Analytical Review in Malaysia. Paper presented at International Kyoto Workshop, organised by Durham University and Kyoto University on $7^{\text {th- }} 8^{\text {th }}$ July 2008, Durham, UK. 